\title{
Positive Study on the International Competitiveness of China's Cotton Products
}

\author{
Chunxiang Liu \\ International Economics and Trade School \\ Ningbo University of Finance \& Economics \\ Ningbo, Zhejiang, China \\ 171653939@qq.com
}

\author{
Yalan $\mathrm{GaO}^{*}$ \\ International Economics and Trade School \\ Ningbo University of Finance \& Economics \\ Ningbo, Zhejiang, China
}

\begin{abstract}
In order to measure the international competitiveness of China's cotton products, this paper carried out an empirical study by means of RCA, RTA, LnRXA, RC, IIT, EC and DRCC indexes. It also chose America, Australia, India, Greece, Brazil, Uzbekistan, Mexico, Turkey and Burkina Faso these nine cotton export superpowers as the international comparison objects. This paper utilized RCA and EC indexes to make a comparative analysis of the international competitiveness of cotton products among China and those nine countries. The study shows that China's cotton is not competitive at all in the international market. The international competitiveness of China's cotton ranks behind the world's major cotton trade powers whether in RCA, IIT or EC index, but American, Australian and Brazilian cotton takes an absolutely dominant position. Lastly, this paper provided some suggestions in order to lift the international competitiveness of China's cotton products, such as optimizing the distribution of cotton production, strengthening the promotion of advanced and practical technology, carrying out direct subsidy and establishing a new national cotton reserve mechanism in line with WTO trade rules.
\end{abstract}

Keywords - cotton products; international competitiveness; international comparison; comparative advantage

\section{INTRODUCTION}

The comparative advantage index is the most used when analyzing a product's competitiveness. However, most researches only use a single index to analyze the international competitiveness of cotton products[1-4]. In order to measure the international competitiveness of China's cotton products more objectively, this paper will establish a comparative advantage index system to measure the international competitiveness of China's cotton products and to overcome limitations of using a single index.

\section{EVALUATION INDEXES SELECTION}

The first index this paper chose to measure the international competitiveness of China's cotton products is revealed comparative advantage (RCA) index which was originally introduced by Balassa (1965)[5] and is defined by:

$$
R C A=\frac{X_{i} / X_{i t}}{X_{w} / X_{w t}}
$$

Where RCA refers to Balassa RCA index of Country i's cotton products, Xi refers to the exports of Country i's cotton

Chunxiang Liu, Study on the diagnosis and development potential of agricultural trade barriers between China and the countries along the Belt and Road, No. 18BJY151, National Fund for Philosophy and Social Sciences. products, Xit refers to the total exports of Country i, Xw refers to the total exports of all the cotton products in the world, and Xwt refers to the exports of all products of all the countries in the world. So, this index is equal to the proportion of the cotton products' exports of a country that are of the total exports of the country divided by the proportion of the cotton products' exports of the world that are of the total exports of the world. The country has a revealed comparative advantage in exporting cotton products if $\mathrm{RCA}>1$. Otherwise, it has a revealed comparative disadvantage in exporting cotton products.

The second index this paper chose to measure the international competitiveness of China's cotton products is relative export advantage index LnRXA which was introduced by Vollrath (1991) [6] and is defined by:

$$
\operatorname{Ln} R X A=\operatorname{Ln} \frac{X_{i} / X_{i t}}{X_{w} / X_{w t}}
$$

Where RXA refers to the revealed export advantage index and its calculation method is the same as Balassa revealed comparative advantage index. That is, RXA=RCA. The country has a relative comparative advantage in the export of its cotton products if LnRXA $>0$. Otherwise, it has a relative comparative disadvantage.

The third index this paper chose to measure the international competitiveness of China's cotton products is revealed trade advantage (RTA) index which was also put forward by Vollrath (1991) [6] and is defined by RTA= RXARMA

RMA refers to revealed import index which is defined by:

$$
R M A=\frac{M_{i} / M_{i t}}{M_{w} / M_{w t}}
$$

Where Mi refers to the imports of Country i's cotton products, Mit refers to the total imports of Country i, MW refers to the total imports of all the cotton products in the world, and MWt refers to the imports of all products of all the countries in the world. The country has a revealed comparative advantage in importing cotton products if RMA $>1$. Otherwise, it has a revealed comparative disadvantage in importing cotton products. So,

$$
R T A=R X A-R M A=\frac{X_{i} / X_{i t}}{X_{w} / X_{w t}}-\frac{M_{i} / M_{i t}}{M_{w} / M_{w t}}
$$


cotton products then produced have international

The country has a revealed comparative advantage in the trade of cotton products if RTA $>0$. Otherwise, it has a revealed comparative disadvantage in the trade of cotton products.

The fourth index this paper chose to measure the international competitiveness of China's cotton products is revealed competitiveness (RC) index which is defined by:

$$
R C=\operatorname{Ln} R X A-\operatorname{Ln} M X A=\operatorname{Ln} \frac{X_{i} / X_{i t}}{X_{w} / X_{w t}}-\operatorname{Ln} \frac{M_{i} / M_{i t}}{M_{w} / M_{w t}}
$$

The country's cotton products have revealed competitiveness if RC $>0$. Otherwise, they do not have revealed competitiveness.

The fifth index this paper chose to measure the international competitiveness of China's cotton products is intra-industry trade (IIT) index which was put forward by Grubel and Lloyd (1975) [7] and is defined by:

$$
I I T=1-\frac{\left|X_{i}-M_{i}\right|}{X_{i}+M_{i}}
$$

IIT changes between 0 and 1 . The closer the value approaches to 1 , the higher the intra-industry trade degree of the cotton product is, and the increasingly uncompetitive the cotton product is; the closer the value approaches to 0 , the more competitive the cotton product is.

The sixth index this paper chose to measure the international competitiveness of China's cotton products is export competitiveness (EC) [8] index which is defined by:

$$
E C=\frac{X_{i}-M_{i}}{X_{i}+M_{i}}
$$

EC changes between -1 and 1 . Generally, when EC is between 0.5 and 1 , the cotton product has a higher competitive advantage; when EC is between 0 and 0.5 , the cotton product has a lower competitive advantage; when EC is between -1 and -0.5 , the cotton product has a higher competitive disadvantage; when EC is between -0.5 and 0 , the cotton product has a lower competitive disadvantage.

The seventh index this paper chose to measure the international competitiveness of China's cotton products is domestic resource costs (DRC) coefficient which was put forward by Pearson (1973) [9]in the theory of domestic resource costs. If a country takes up in production activity $\mathrm{j}$ in order to earn or save a margin unit foreign exchange under trade liberalization, the domestic resource cost DRCj it needs to input is:

DRC $\mathrm{j}=$ domestic resource costs Country $\mathrm{j}$ inputs in cotton production activity/net foreign exchange earnings or saving

$$
\operatorname{DRCC}_{j}=\frac{D R C_{j}}{V_{i}}
$$

DRCCj can be used to evaluate the international competitiveness of a country's cotton products because it has no unit. If $\mathrm{DRCC}=1$, the cotton product production of the country has no comparative advantage and as a result, such cotton products then produced do not have international competitiveness; if DRCC $\mathrm{D}<1$, the cotton product production of the country has comparative advantage and as a result, such competitiveness, plus smaller DRCCj means higher competitive advantages; if DRCC $>1$, the production of such cotton products has no comparative advantage and as a result, such cotton products then produced do not have international competitiveness, plus greater DRCCj means higher comparative disadvantages.

\section{THE SPECIFIC MEASUREMENT OF THE COMPETITIVENESS OF CHINA'S COTTON PRODUCTS}

\section{A. The international competitiveness of China's cotton products under RCA, RTA, LnRXA and RC indexes}

RCA, RTA, LnRXA and RC indexes are combined to measure the international competitiveness of China's cotton products (see Table I) because they are tightly related [10]. Generally, when a product's RCA $>1$ and LnRXA, RTA and $\mathrm{RC}$ are all positive, this product has comparative advantages and competitiveness.

TABLE I. COMPARATIVE ADVANTAGE AND COMPETITIVENESS INDEXES OF CHINA'S COTTON PRODUCTS

\begin{tabular}{|c|c|c|c|c|c|c|c|}
\hline \multicolumn{4}{|c|}{ Average value (2000-2016) } & \multicolumn{5}{c|}{2016} \\
\hline RCA & LnRXA & RTA & RC & RCA & LnRXA & RTA & RC \\
\hline 0.558 & -1.169 & -1.903 & -1.624 & 0.021 & -4.792 & -3.662 & -6.109 \\
\hline
\end{tabular}

Table 1 shows that whether from the perspective of average values of all indexes over the years or from the situation of 2016, China's cotton doesn't have any comparative advantages or international competitiveness, because the average RCA index between 2000 and 2016 is less than 1 and LnRXA, RTA and RC indexes are all less than 0 . Besides, both comparative advantages and international competitiveness of China's cotton products tend to decline for the statistics in 2016 are all less than the average values between 2000 and 2016.

\section{B. The international competitiveness of China's cotton products under IIT and EC indexes}

IIT and EC indexes are combined to measure the international competitiveness of China's cotton products (see Table II) because they are tightly related [11]. If the product has a trade surplus, IIT=1-EC; if it has a trade deficit, $\mathrm{IIT}=1+\mathrm{EC}$.

TABLE II. INTRA-INDUSTRY TRADE AND EXPORT COMPETITIVENESS INDEXES OF CHINA'S COTTON PRODUCTS

\begin{tabular}{|c|c|c|c|c|c|c|c|}
\hline \multicolumn{2}{|c|}{2000} & \multicolumn{2}{c|}{2003} & \multicolumn{2}{c|}{2010} & \multicolumn{2}{c|}{2016} \\
\hline IIT & EC & IIT & EC & IIT & EC & IIT & EC \\
\hline 0.617 & 0.383 & 0.899 & -0.801 & 0.804 & -0.996 & 0.911 & -0.963 \\
\hline \multicolumn{6}{|c|}{ EC index in Table II shows that the international }
\end{tabular}
competitiveness of China's cotton products has been gradually decreasing as a whole. For example, cotton products had a lower competitive advantage as a whole in 2000. The EC index then was 0.383 and declined to -0.996 in 2010, which means that the cotton products had a higher competitive disadvantage.

The intra-industry trade index of China's cotton products has been on the rise, which indicates that China's cotton 
A. Comparison of international competitiveness of all countries' cotton products under RCA

TABLE IV. COMPARISON OF RCA OF OTHER COUNTRIES’ COTTON PRODUCTS AND THAT OF CHINA’S IN 2016

Because it is hard to obtain a set of complete data of opportunity cost and shadow foreign exchange, this paper can only measure the international competitiveness of China's cotton products on the basis of previous academic studies. It utilizes the domestic resource costs coefficient DRCC to measure the international competitiveness of China's cotton and see Table III for details. DRCC reflects the number of units of costs a country that produces an agricultural product needs to input to obtain a unit of shadow income, when production factors, labor services and products can flow freely among countries [12-14]. If DRCC $<1$, the product has a comparative advantage for its production output is greater than input; if DRCC $>1$, the product lacks international competitiveness for its production output is less than input. If DRCC $=1$, the product is at the balance point of international competitiveness for its output is equal to input. So this index can also apply to cotton.

TABLE III. DRCC VALUE OF CHINA's COTTON PRODUCTS

\begin{tabular}{|c|c|c|c|c|c|}
\hline 1991 & 1995 & 2000 & 2005 & 2010 & 2016 \\
\hline 0.4718 & 0.6505 & 0.8212 & 0.8309 & 0.9107 & 1.0032 \\
\hline
\end{tabular}

Table III shows that DRCC of China's cotton products has gradually increased to 1.0032 in 2016 from 0.4718 in 1991, which indicates higher competitiveness turning to noncompetitiveness. These features are determined by China's resource endowments that China is abundant in labor resources but short of cultivated areas. Anderson and Hayami thought that the more one country is short of cultivated area resources, the faster its economy grows and its agricultural comparative advantage declines. You can see this conclusion from Anderson, Hayami, et al. in 1996, whose article is named the Political Economy of Agricultural Protection (Chinese version), Tianjin People's Publishing House, 1996. The change of the international competitiveness of China's cotton products happens to match this feature which is that landintensive cotton products are losing their international competitiveness.

\section{INTERNATIONAL COMPARISON OF COMPETITIVENESS OF CHINA'S COTTON PRODUCTS}

For easier comparison and to find the gap, this paper chose America, Australia, India, Greece, Brazil, Uzbekistan, Mexico, Turkey and Burkina Faso these nine cotton export powers as objects of international comparison. Taking the year 2016 as an example, it utilized RCA and EC indexes to make a comparative analysis.

\begin{tabular}{|c|c|c|c|c|}
\multicolumn{5}{c}{ PRODUCTS AND THAT OF CHINA's IN 2016} \\
\hline China & America & Australia & India & Greece \\
\hline 0.014 & 6.188 & 4.045 & 4.332 & 3.372 \\
\hline Brazil & Uzbekistan & Mexico & Turkey & Burkina Faso \\
\hline 4.491 & 3.083 & 1.675 & 1.046 & 0.813 \\
\hline
\end{tabular}

Table IV shows that in descending order of the revealed comparative advantage index of ten countries' cotton in 2016, they are America, Brazil, India, Australia, Greece, Uzbekistan, Mexico, Turkey, Burkina Faso and China. Except for Burkina Faso and China, other countries' cotton products all have revealed comparative advantages and their RCA values are all greater than 1. The RCA value of America in 2016 reached 6.188, which is 442 times of China (0.014).

\section{B. International competitiveness of China's cotton products under EC}

TABLE V. COMPARISON OF EC OF OTHER COUNTRIES' COTTON PRODUCTS AND THAT OF CHINA'S IN 2016

\begin{tabular}{|c|c|c|c|c|}
\hline China & America & Australia & India & Greece \\
\hline-0.814 & 0.524 & 0.503 & 0.105 & 0.372 \\
\hline Brazil & Uzbekistan & Mexico & Turkey & Burkina Faso \\
\hline 0.601 & 0.314 & 0.016 & -0.163 & -0.215 \\
\hline
\end{tabular}

Table $\mathrm{V}$ shows that in descending order of the export competitiveness index of ten countries, they are Brazil, America, Australia, Greece, Uzbekistan, India, Mexico, Turkey, Burkina Faso and China. Brazilian, American and Australian cotton products all have export competitiveness and their EC indexes are all greater than 0.5; but China's EC index value is only -0.814 , which means China's cotton products do not have export competitiveness.

\section{CORRESPONDING MEASURES TO IMPROVE THE INTERNATIONAL COMPETITIVENESS OF CHINA’S COTTON}

\section{A. Giving play to comparative advantages and optimize cotton's production layout}

Popularize varieties of bollworm resistant cotton in the light of local conditions to reduce production costs according to features of cotton regions of China's Yellow River and Yangtze River valleys. Vigorously promote intercropping stereo planting technology to increase comprehensive efficiency of cotton production. Accelerate the popularization of new varieties of high-quality, dedicated and special cotton in the light of local conditions, establish large area of highquality, highly productive and efficient cotton science and technology demonstration zones and organize cotton planters to carry out standardized production all over the country. In Xinjiang cotton region, vigorously promote new varieties of high-quality, bollworm resistant, disease resistant, drought resistant and early-maturing cotton, regularize "dense, short and early-maturing" and chemical control planting technology systems, make efforts to improve fiber quality, and increase its competitiveness in the domestic and global cotton markets, so 


\section{Establishing a national cotton reserves mechanism that complies with WTO trade rules}

Cotton is not only a strategic material that is vital to national economy and people's livelihood but also a staple agricultural commodity that is extremely likely to be influenced by fluctuations in the world market price. In recent years, the price of cotton in the global market has been fluctuating all the time. In consequence, China's cotton production will inevitably face severe challenges from the global cotton market after the entry of WTO. In order to ensure healthy and sustainable development of the cotton industry and positively respond to challenges brought by the global cotton market, China should establish a cotton reserves mechanism that complies with WTO trade rules, increase reserves of cotton in China's largest cotton-producing area Xinjiang and establish a depot of 0.75 to 1 million tons of cotton in Xinjiang, so as to adjust cotton market supply and demand, suppress abnormal fluctuation in cotton price, further protect enthusiasm of cotton planters for production and improve those planters' income level.

\section{CONCLUSIONS}

diseases and insect pests, so as to strengthen prevention and control measures and improve the effects. Besides, enhance domestic and international cooperation and exchanges on science and technology and establish an application system for China's cotton scientific and technological innovation and technical promotion.

\section{Implement direct subsidies by means of "amber box" policies}

"Amber box" policies have direct affect on improvement of agricultural competitiveness ${ }^{[16]}$. In three to five years, we should adjust the original cotton subsidy direction. Instead, we should subsidize farmers and agricultural production directly, implement preferential policy on improved varieties, fertilizer and other agricultural means of production and give a certain subsidy. Recently, we need to strive for financial support and implement cotton variety subsidy as soon as possible to change the situation of mass and messy varieties in a short time. Since the Seed Law was enacted, cotton seed operation has been liberalized, all kinds of operational entities have entered the cotton seed sales market, and cotton planters have had autonomy in management and been able to select varieties independently. As a result, to restrict farmers to planting certain varieties by governmental executive orders is no longer realistic. Instead, we may reduce cotton varieties through guidance in the short run. To give a certain subsidy to mainly planted varieties of cotton and to give subsidies to production processes and farmers directly not only comply with the "amber box" policies of WTO rules but also can solve the problem of mass and messy cotton varieties effectively. It is possible to only grow one or two varieties in a suitable ecological region or area through subsidy, which is good for preserving the pure state of seeds, extending the service life of existing cotton varieties, making full use of features of all ecological regions and advantages of high-quality cotton varieties, and controlling the consistency of the quality of lint cotton, so as to better meet the demands of the textile sector.
We can come to the following conclusions from the above analysis:

1) China's cotton has no competitiveness in the international market. Whether in RCA index, IIT index or EC index, the international competitiveness of China's cotton all comes behind that of the world's major cotton trade powers.

2) The export competitive advantage of China's cotton has declined rapidly within a year or two since China enters WTO [15]. From the perspective of three indexes before the entry of WTO, China's cotton has competitive advantages to some extent. But it completely lost competitive advantages after the entry of WTO, especially after 2003. Though the entry of WTO promotes the development of China's textile industry, it largely weakens the international competitiveness of China's cotton.

3) American, Australian and Brazilian cotton has absolute competitive advantages. From the perspective of three indexes to measure international competitiveness, both America and Australia rank the top among the world's major cotton import and export countries with evident competitive advantages.

\section{REFERENCES}

[1] Bruckmeier K, LARSEN C H, "Swedish coastal fisheries-from conflict mitigation to participatory management,” Marine policy vol. 2, pp. 201-211, 2008.

[2] Wang Yongde, Study of the International Competitiveness of China's Agricultural Products-based on Comparison between China and America. Beijing: China Agriculture Press, 2009 (In Chinese).

[3] Wen Tiejun, Rural Issues \& Institutional Evolution. Beijing: China Economic Publishing House, 2009(In Chinese).

[4] Li Qinchang, Chang Min, "Upgrading Path of International Competitiveness for Chinese Cotton Industry,” Journal of International Trade, vol.10, pp. 34-47, 2011(In Chinese).

[5] Balassa, B., "Trade liberalization and 'revealed' comparative advantage”, The Manchester School of Economic and Social Studies, vol. 33, pp. 99-123, 1965. 
Economics, vol. 1, pp. 4-9, 2008(In Chinese).

[6] Vollrath, T. L., "A theoretical evaluation of alternative trade intensity measures of revealed comparative advantage”, Weltwirtschaftliches Archiv, vol. 130, pp. 265-279, 1991.

[7] Grubel, H. G. and Lloyd, P. J, Intra-Industry Trade: the Theory and Measurement of International Trade in Differentiated Products. Macmillan, 1975.

[8] Verdoorn, P. J, The intra-bloc trade of Benelux, in E. A. G. Robinsoned. Economic Consequences of the Size of Nations, ST. Martin's Press, INC, 1960

[9] Pearson, S. R., Net profitabolity, domestic resource costs, and effective rate of protection, food research institute, Stanford University, Mimeographed, 1973.

[10] Zhu Xigang, Zhang Shemei, Zhao Zhijun, “Analysis on China's Cotton Production Efficiency Change in Recent Years,” Issues in Agricultural Economy, vol. 4, pp. 9-13, 2007(In Chinese).

[11] Zhong Funing, Hu Xuemei, "Study of China's Cotton Production Regional Pattern and Influential Factors,” Journal of Agritechnical

12] Liu Zhixiong, "The Impact of China's Cotton Domestic Support Policies on the World Cotton Market,” Issues in Agricultural Economy, vol. 8, pp. 33-39,110-111, 2014(In Chinese).

[13] Luo Xingwu, Tan Jingrong, Yang Xingwu, “Analysis of Effects of Non-tariff Measures on the Imports of China's Staple Agricultural Commodities-Taking Soybeans, Cotton, Vegetable Oil, Grain and Sugar as Examples,” Issues in Agricultural Economy, vol.3, pp. 62-67, 2014(In Chinese).

[14] Su Bin, "Industrialized Operation is An Inevitable Choice of the Development of Cotton Industry in Xinjiang," Social Sciences in Xinjiang, vol. 2, pp. 47-49, 2002(In Chinese).

[15] World Economic Forum (WEF), “The Global Competitiveness Report,” 2003, 2018.

[16] Winters, L. A, “The British in Europe: an evidence of quantitative trade research,” Journal of Economic Studies, vol. 26, pp. 105-111, 1987. 